\title{
BASM and the recognition of 'sports medicine'
}

The clinician's Pavlovian tendency to turn against colleagues rather than to make common cause also exists in sports medicine. We can learn from this expression of frustration at our lack of recognition.

BASM has battled for four decades to achieve public recognition of 'sports medicine'. In a country including both a near-monopoly National Health Service and an ambiguous succession of mechanisms for expressing Government interest in sport, it has at times been difficult to know if our script followed Disney or Kafka.

Nevertheless BASM, funded solely by its own members' interest, enthusiasm, energy and money, grew to 1600 , acquired representative status at home and abroad, started a journal and instituted the first sports medicine syllabus and courses in Britain. BASM courses since 1975 have provided sports medicine education at different levels to over 1500 British doctors and physiotherapists who underpin the claim that British sports medicine has de facto, arrived, although it remains under-recognized.

Governments have much to answer for. Over the years in which BASM developed a forum for sports medicine interest, education and growth, and almost every other country in Europe acquired sports medicine, the Sports Council refined various ways of avoiding commitment by playing elitism against mass participation; medicine against science; centre against regions; Council rather against Olympic movement then rather strongly for it. Scottish clinics were supported: England was told this was not possible. BASM was told a secretary could not be funded: the sports scientists had a secretary paid for. The background theme remains, the only consistency through the years, 'but we're not going to pay for the NHS'. Now, of course, this is vindicated by the atavistic morality of the market place in which only rich, insured or sponsored athletes need expect top sports medical treatment and desperate hospital 'Trusts' smell only money in the pathology of sport.

The first Sports Council's doctrinaire refusal to develop sports medicine centres of excellence allowed such initiatives to pass abroad. Later, in 1979, it refused even to publish its first policy on sports medicine! Finally it contrived, in forming the National Sports Medicine Institute two and a half years ago, to destroy the good will and practical efforts of its predecessor London Institute. Government support of this new enterprise has to predicate the arrival of (privatized) National Lottery funds! Now even the UK Sports Council is to be replaced by a central committee for elite sport while the government drops 'Sports for All' into the underfunded lap of local authorities - hardly cheering for the NSMI's political prognosis.

Clinicians dedicated to the never-ending stream of the sport-afflicted are entitled to have this mission recognized instead of taken for granted.

'Sport', participants and their governing bodies and the Sports Councils must show more convincingly that they really want proper services. This means paying for them (what other branch of medicine is expected to give itself free?) or negotiating the way in which services will actually reach the athlete. We are all tired of having sports medicine taken less seriously than our other duties and of putting up with denigration from press, patients and, of course, governing bodies, Government and Sports Councils alike when they themselves control the means to commission our services.

Doctors cannot impose their services. These must be paid for and organized. Has the Sports Council or the Government even tried to ensure that the NHS provides rather than tolerates 'sports medicine'? Of course not - money and dogma call the tune! Britain has just two NHS consultants so far in sports medicine.

Things are changing. The British Medical Association's recent recognition of sports medicine is politically vital and the formation of the Royal Society of Medicine's section of sports medicine is a major step in medical establishment recognition.

We need now, within BASM, to define and express our criteria for professional training and recognition to avoid being represented by strangers to sports medicine or looking inadequate in direct comparison to the stringent criteria laid down for all other medical specialties.

As fellow enthusiasts for sports medicine, we should recognize that common interest, sink at least some of our various differences, and put real effort into strengthening and professionalizing our own representative body. We were promised a business development plan two years ago. Nothing has been done. Membership is static rather than growing. A member survey is a year overdue. Lack of organizational discipline besets BASM, its education programme runs at a loss and the long overdue constitutional review cannot be ready for even this year's AGM - and is in any case a tinkering with the old flawed constitution rather than the radical rethink so badly required. It should not, for instance, be assumed that BASM is forever advantaged by its present legal status as Charity law forbids us either to be a union or to trade. Members should think hard what they want, express it clearly and take a full part in BASM's representative activities. 